\title{
Function and potentials of M. tuberculosis epitopes
}

\author{
Juraj Ivanyi * \\ Guy's Hospital, Kings College London, London, UK
}

\section{Edited by:}

Tom H. M. Ottenhoff, Leiden University Medical Center,

Netherlands

\section{Reviewed by:}

Tom H. M. Ottenhoff, Leiden University Medical Center, Netherlands

Annemieke Geluk, Leiden University Medical Center, Netherlands

*Correspondence:

Juraj Ivanyi, Guy's Hospital, Kings

College London, Hodgkin Building,

London SE1 1UL, UK

e-mail: juraj.ivanyi@kcl.ac.uk
Study of the function of epitopes of Mycobacterium tuberculosis antigens contributed significantly toward better understanding of the immunopathogenesis and to efforts for improving infection and disease control. Characterization of genetically permissively presented immunodominant epitopes has implications for the evolution of the host-parasite relationship, development of immunodiagnostic tests, and subunit prophylactic vaccines. Knowledge of the determinants of cross-sensitization, relevant to other pathogenic or environmental mycobacteria and to host constituents has advanced. Epitope-defined IFN $\gamma$ assay kits became established for the specific detection of infection with tubercle bacilli both in humans and cattle. The CD4 T-cell epitope repertoire was found to be more narrow in patients with active disease than in latently infected subjects. However, differential diagnosis of active TB could not be made reliably merely on the basis of epitope recognition. The mechanisms by which HLA polymorphism can influence the development of multibacillary tuberculosis (TB) need further analysis of epitopes, recognized by Th2 helper cells for B-cell responses. Future vaccine development would benefit from better definition of protective epitopes and from improved construction and formulation of subunits with enhanced immunogenicity. Epitope-defined serology, due to its operational advantages is suitable for active case finding in selected high disease incidence populations, aiming for an early detection of infectious cases and hence for reducing the transmission of infection. The existing knowledge of HLA class I binding epitopes could be the basis for the construction of T-cell receptor-like ligands for immunotherapeutic application. Continued analysis of the functions of mycobacterial epitopes, recognized by $T$ cells and antibodies, remains a fertile avenue in TB research.

Keywords: tuberculosis, antigenic structure, epitope mapping, immunodominant epitopes, immunodiagnosis, immunotherapy, immunopathogenesis

\section{INTRODUCTION}

Pathogenic bacteria produce a wide range of constituents, which determine their virulence and host responses following infection. In the case of Mycobacterium tuberculosis (Mtb), antigenic and immunomodulatory constituents may be considered as virulence factors, because they can act as "decoys," triggering excessive immune responses which can lead to pathology of the lungs in active tuberculosis (TB), instead of host protection (1). Hence, immunological research has been essential for the study of pathogenesis as well as for the development of prophylactic vaccination and for the detection of latent infection. Detailed analysis of the specificity and of the phenotype of immune responses is mandatory in the desire to discover biomarkers for protective immunity, for predicting the risk of reactivation from latent infection and for developing immunotherapies, adjunct to chemotherapy.

Dissection of the antigenic structure of Mtb to its epitope constituents has been driven by the newly developed technologies, starting with hybridoma-produced monoclonal antibodies $(2,3)$, followed by recombinant DNA expression libraries (4), T-cell cloning and hybridomas (5), and DNA sequencing. More recently, new epitopes predicted within the whole Mtb genome on the basis of algorithms ("silico mapping") (6) have a useful rate of empirical confirmation (7). The location of discontinuous and conformational epitopes recognized by antibodies can be predicted by integrated analysis of the dynamical and energetic properties of proteins (8). Mapping of T-cell epitopes within the known protein sequence used synthetic peptides with overlapping sequence ("pepscan") and single-residue substitutions identified epitope cores, flanks, and key residues involved in binding to major histocompatibility complex (MHC) or T cell receptor (TcR) molecules.

Characterization of the membrane markers and cytokine profiles of responding $\mathrm{T}$ cells identified the existence of $\mathrm{T}$-cell subsets and their regulatory networks. Emphasis on the T-cell phenotype and recently on the transcriptomic signature of $\mathrm{T}$ cells is currently expanding (9), but without full attention to antigen and epitope specificity. However, restoring the balance of knowledge between the functional phenotype and recognition specificities of $\mathrm{T}$ cells seems compelling.

The extensive knowledge on the mapping of antigenic epitopes has been cataloged and made accessible by the NIH IEDB database http://www.ncbi.nlm.nih.gov/pmc/ articles/PMC2228276/; http://www.iedb.org/; http://help.iedb. org/entries/19150-user-documentation-iedb-version- 2 .

This inventory contains more than 1000 epitopes, mostly derived from only about 30 of the most immunogenic antigens, 
representing a very small fraction from the about 4000 known open reading frame proteins of the Mtb genome (10). Recently combined analysis of epitope predictions, high throughput ELISPOT, and T-cell libraries from latently Mtb-infected subjects, categorized the epitopes into prominent "antigenic islands" (11). The wider significance of epitope specificity of immune responses of Mtb-infected hosts has been reviewed recently (12).

This chapter points out the role of individual epitope specificities and aims to integrate this knowledge with different functions, relevant for the host-parasite relationship. Potentials for future research are targeted at improving the control of $\mathrm{TB}$, particularly for vaccination, immunotherapy, detection of latent infection, and early diagnosis of infectious forms of active disease.

\section{MHC-PERMISSIVE EPITOPES}

Immunodominant epitopes were originally thought to be recognized in the context of only one or a few MHC class II alleles, though a number of genetically permissive epitopes were found in microbial pathogens. Initial mapping of CD4 T-cell stimulatory epitopes showed two hsp65 peptides recognized by several H-2disparate mouse strains, one of them presented by both I-A and I-E molecules (13). Subsequent analysis of two glyco-lipoproteins and the $\alpha$-crystallin (Acr) antigen identified the same few epitopes as immunodominant in a number of inbred strains of mice, carrying different $\mathrm{H}-2 \mathrm{~A}$ alleles (14-16). H2I-A promiscuous recognition of p350-369 was demonstrated using CD4 T-cell hybridomas, though with allele-specific binding of IA polymorphic critical residues (17). Moreover, pepscan analysis revealed separate patterns of recognition by $\mathrm{T}$ hybridomas of the same $\mathrm{H}-2$ haplotype, whereby every core residue was critical for at least one hybridoma, with only one substitution $(74 \mathrm{Val} \rightarrow \mathrm{Ala})$ common to all hybridomas (18). While core residues were critical for both MHC and TcR binding, T-cell recognition was influenced also by the substitution of flanking residues (19).

The apparently abundant occurrence of MHC-permissive epitopes in tubercle bacilli may be an evolutionary consequence of selection of mutants carrying protective MHC-permissive epitopes. These organisms would have been advantageous to the pathogen, by being conducive to the longer survival of individuals, who were capable of aerosol transmission of the infection. This evolutionary concept is supported by the finding that $\mathrm{T}$ hybridomas from $\mathrm{H}-2 \mathrm{Ab} / \mathrm{d}$ heterozygous mice had a higher frequency of IA-promiscuous recognition than hybridomas from each of the parental H-2 homozygous hybridomas (17). The IA-promiscuous hybridomas could also be stimulated with lower peptide concentrations, indicating TcR recognition of higher TcR affinity. Selection of MHC-permissive epitopes by low antigen concentrations in chronically Mtb-infected outbred populations would have had the advantage for the protection and survival of the infected hosts.

Analysis of HLA-DR heterozygous T-cell lines against the permissively recognized 91-110 epitope of the Acr antigen also showed superior stimulation in the context of heterozygous antigen presenting cells (APCs) (20). Moreover, stimulation in the context of DR-homozygous APCs showed that the HLA-DR haplotype influenced not only the magnitude, but also the IFN $\gamma / \mathrm{IL}-4$ secretion profiles of the T-cell lines. The demography and evolution of Mtb lineages, virulence, and selection of epitopes of conserved structure were suggested also as an adaptation to other genetically diverse constituents in human macrophages, but without due consideration of the selective role of the HLA system for the selection of permissive epitopes (21).

The definition of MHC-permissive epitopes is mandatory for further development of both diagnostics and vaccines with a potential to function in large sections of genetically diverse human populations. HLA class II-permissive epitopes have been identified in a number of antigens of different structure, such as PstS1 glycolipoprotein (22), heat shock proteins hsp65 (23), and GroES (24), Acr (25), ESX proteins $(26,27)$, secreted proteins Ag85B (28) and MPB70 (29), and PE/PPE proteins (30) (Table 1). The abundance of human CD4 and CD8 T-cell responses to the respective epitopes was explained by their permissive binding to several HLA-DR (15, $22,31,32)$ and also HLA class I $(26,33,34)$ molecules.

Detailed analysis of the p350-369 epitope of PstS1 (35) showed a range of binding affinities to different DR molecules and identified the epitope core to be of 9-11 residues. Binding to both DR1 and DRB5 $5^{\star} 0101$ shared F-354 as the common primary contact residue. Molecular modeling suggested that the peptide bound to DR1 in the elongated conformation as usual for MHC class II molecules, but in a "kink," when bound to $\mathrm{DRB} 55^{\star} 0101$, which is common for peptides bound to MHC class I complexes. The possible influence of different conformations imposed on the same peptide by distinct HLA alleles on T-cell responses has yet not been elucidated.

Substitution of single amino acids in the epitope core has been employed to identify both HLA-DR and TcR-binding contact residues within the DR17 restricted p3-13 epitope from the hsp65 antigen. Using this approach, TcR V gene families of human CD4 T-cell clones were analyzed in respect of the most immunodominant, HLA-DR promiscuous 91-110 epitope of Acr (25). The HLA-DR-binding and TcR-binding cores and contact residues were identified within 9-mer or 13-mer cores, which differed between the DR haplotypes. Notably, preferential TcR usage was demonstrated by the finding that the majority of clones used the BV2 TcR and contained a common R-L/V-G/S-Y/W-E/D sequence motif in the CDR3 region (36). These data may be useful to design peptides with altered HLA anchor residues or TcR interaction sites to increase their immunogenicity.

The "in silico" algorithms (ProPred1) predicted a number of HLA class I-permissive epitopes in histone or proteins of undefined function from Mtb (37). ProPred prediction of Mycobacterium leprae epitopes identified a number of both class I and II, HLA-permissive T-cell reactivity, in leprosy endemic populations in Brazil, Ethiopia, and Nepal (38). Comparing algorithms for HLA-binding promiscuity between ecologically diverse human microbial pathogens, found the promiscuity of Mtb epitopes to be of a similar degree as in HIV, S. pyogenes, or even higher for B. anthracis and C. tetani (39). However, these epitope predictions need empirical confirmation and should take into account that HLA binding affinities may not always associate with the magnitude of T-cell responses.

\section{CROSS-REACTIVITY OF MYCOBACTERIAL EPITOPES}

The antigens of $\mathrm{Mtb}$ are related to a number of proteins from non-tuberculous mycobacterial pathogens or commensal 
Table 1 | Mtb antigens with identified HLA-DR-permissive CD4+ T-cell stimulatory epitopes.

\begin{tabular}{|c|c|c|c|c|c|}
\hline Protein group & Antigen name & Gene accession no. & kDa & Epitope sequence & Reference \\
\hline Glyco-lipoprotein & PstS1 & Rv0934 & 38 & $1-20 ; 350-369$ & Jurcevic et al. (22) \\
\hline \multirow[t]{3}{*}{ Chaperonin stress proteins } & $\alpha$-Crystallin, Acr & Rv2031 & 16 & $91-110$ & Caccamo et al. (25) \\
\hline & GroEL2, hsp65 & $\mathrm{Rv0440}$ & 65 & $61-75 ; 141-155$ & Mustafa et al. (23) \\
\hline & GroES & Rv3418c & 10 & $25-40$ & Chua-Intra et al. (24) \\
\hline \multirow[t]{2}{*}{ RD-1, ESX family } & ESAT-6, EsxA & Rv3875 & 6 & $1-20$ & Tully et al. (27) \\
\hline & CFP-10, EsxB & Rv3874 & 10 & $71-88$ & Shams et al. (26) \\
\hline \multirow[t]{2}{*}{ Secreted proteins } & Ag85B mycolyl transferase & Rv1886c & $30-32$ & $91-108$ & Valle et al. (28) \\
\hline & MPB70, mpt70 & Rv2875 & 22 & $106-130,166-190$ & Al-Attiyah et al. (29) \\
\hline Cell surface & PPE family & Eight genes & $3-316$ & Eight epitopes & Wang et al. (30) \\
\hline
\end{tabular}

non-pathogenic mycobacterial species and more rarely with human proteins. These relationships are of interest, because environmental priming can influence resistance to $\mathrm{Mtb}$, it can interfere or enhance the protective immune response to vaccination and may exclude from vaccine development, any molecules that can lead to autoimmunity. The latter category includes the chaperonins hsp65 and hsp71 with highly conserved sequences between prokaryotic and eukaryotic species and consequently extensive cross-reactivity between mycobacteria and humans (40). An hsp65 epitope at sequence 285-295, detected by mAb ML30 is strongly expressed on the surface of human cells with abundant mitochondria (40). Elevated expression was observed on monocyte-derived cells in different inflammatory diseases, including rheumatoid arthritis (41), atherosclerosis (42-44), and multiple sclerosis (45).

Analysis of antigen homologs from different species of mycobacteria showed that cross-recognition by $\mathrm{T}$ cells requires sharing fewer amino acids than cross-reaction by antibodies. Thus, polyclonal and monoclonal antibodies to ESAT-6 from Mtb and $M$. leprae, which share only $36 \%$ amino acids, are all strictly speciesspecific (46). In contrast, recombinant ESAT- 6 from both species are similarly recognized by $\mathrm{T}$ cells from individuals, who were exposed to either tuberculous or leprosy infection (46). Crossreactivity at the level of $\mathrm{T}$-cell, but not $\mathrm{B}$-cell recognition can lead to the recall of antibody production with specificity for the initial antigen (termed: "original antigenic sin") (47). This interpretation was given to the finding of elevated antibody levels against Mtbspecific epitopes in lepromatous leprosy patients from TB endemic areas (48). However, $M$. leprae-specific antibodies in patients with active TB were not raised, since these patients were probably not exposed to M. leprae infection.

Cross-reactivity without sequence homology, i.e., mimicry, has been observed with a broad range of molecules of different structure, such as lactoferrin, transferrin, and proteoglycan. Another example of mimicry is the cross-recognition by CD4 T cells of an octamer epitope on two unrelated mycobacterial proteins, which is immunodominant for the $19-\mathrm{kDa}$ protein of $\mathrm{Mtb}$ and cryptic for the $28-\mathrm{kDa}$ protein of $M$. leprae $(49,50)$. Assumptions that epitope-based mimicry between proteins could lead to unsuspected cross-sensitization, maintain T-cell memory, or lead to autoimmunity, need further study.
Despite wide sequence homologies, heat shock proteins contain also species-specific epitopes. Increased Mtb-specific antibody levels were reported for hsp65, hsp71 $(51,52)$ in patients with active $\mathrm{TB}$, including patients with smear-negative disease, which remains a diagnostic obstacle. Elevated serum antibodies to mycobacterial, but not to human hsp65 in Crohn's disease, implied a pathogenic role of mycobacteria, whereas antibodies in ulcerative colitis bound to human hsp65 (53). Further support for the mycobacterial pathogenesis of Crohn's disease came from the finding of elevated antibody levels against three different antigens derived from Mycobacterium paratuberculosis (54).

Immunodominant species-specific T- and B-cell epitopes can be found in a mycobacterial $10-\mathrm{kDa}$ GroEL heat shock protein despite its highly conserved amino acid sequence. Despite a $90 \%$ sequence identity with $\mathrm{Mtb}$, studies in mice identified two $M$. leprae-specific closely overlapping CD4 T-cell epitope cores (2434 and 28-34), restricted by H-2Ad and H-2Ed, respectively and overlapping with an M. leprae-specific mouse mAb (ML6 and 10) epitope at residues 25-31 (55). The lack of antibody response to this epitope in lepromatous leprosy patients was suggested to be due to the T-cell epitope overlap.

The CD4 T-cell epitope repertoire of GroES was investigated also in TB and leprosy patients. The $\mathrm{N}$-terminal (1-16) peptide (residues 1-16) was specifically stimulatory in the majority of active TB patients (56), while none of the other peptides was discriminatory. On the other hand, peptide 25-40 (29-37 core) of M. leprae, but not of Mtb sequence was specifically stimulatory in tuberculoid leprosy patients; this peptide bound to a number of HLA-DR molecules, of which HLA-DRB $5^{\star} 0101$ had the strongest affinity (24). Four other leprosy-specific epitopes were identified on the $35-\mathrm{kD}$ a protein of M. leprae, which has a homologous constituent in M. avium, but not in Mtb (57). Analysis of epitope specificities explained the phenomenon of split leprosin/tuberculin anergy of skin hypersensitivity in a proportion of leprosy patients. Thus, blood T-cell proliferative responses were found to be diminished to cross-reactive antigens, but elevated toward the predominantly Mtb-expressed PstS1 antigen and the Acr epitope 71-91 (58).

A special case of cross-reactivity is the induction of epitopespecific immune responses by anti-idiotype (Id) antibodies, acting 
as the epitope's "internal image." This was demonstrated for both mouse and human CD4 T-cell responses, using rabbit anti-Ids raised against PstS1-specific mouse mAbs $(59,60)$. However, the corresponding structural determinants remained undefined and the approach has been overtaken by the more exact recombinant DNA and synthetic peptide technologies. Id specificities have also been identified on anti-DNA autoantibodies stimulated probably by bacterial polyclonal B-cell activation in patients with TB and leprosy $(61,62)$.

\section{T-CELL EPITOPE ANALYSIS IN LATENT Mtb INFECTION}

Mycobacterium tuberculosis infection is routinely being monitored by skin delayed type hypersensitivity (DTH) reactions against tuberculin (PPD), a crude extract from M. tuberculosis. This test has poor specificity, due to cross-reaction with environmental mycobacteria and vaccination by Bacillus Calmette-Guerrin (BCG). The discovery of Mtb-specific, immunodominant, HLApermissive epitopes, led to the use of synthetic peptide for the in vitro stimulation of blood T-cell responses. The numerous candidate peptides described (not reviewed here) have all been selected from several antigens on the grounds of better specificity than PPD, but they are performing at lower sensitivity than PPD. Improvements to sensitivity by using peptide pools has however had a limited impact, because of overlapping, rather than complementary recognition by the T-cell repertoire (22). The increase in stimulation by a pool of eight different peptides over the best single peptide (p91-110 from Acr) has been merely marginal. This outcome was attributed to HLA permissiveness and to competition between peptides for a limited number of binding sites on the HLA class II molecules of the APCs. This latter explanation has been supported by the finding of a declining response trend to higher concentrations of pools, but not of single peptides.

Nevertheless, commercially available IFN $\gamma$ detection kits (IGRA), e.g., QuantiFERON-TB Gold (QTF-G), T-SPOT.TB etc. have been widely used for the specific detection of latent Mtb detection. They usually contain a mixture of several epitopes, predicted by algorithms of the Mtb-specific ESAT- 6 and CFP-10 RD-1 antigens (absent from BCG and environmental mycobacteria). However, the use of these kits in areas highly endemic for TB is not of great added value for diagnosis. Recent side-by-side analysis of constituent antigens indicated potentials for further improvement of the test kits (63). Peptide cocktails have also been useful for the diagnosis of bovine TB in cattle, using either skin test or blood assays $(64,65)$. The blood INF $\gamma$ assay (BOVIGRAM) readout has been further enhanced by adsorbing the peptides onto a range of microparticulate and nanoparticulate substrates (66). Detection IFN $\gamma$-induced protein (IP-10), which is produced in 100 -fold greater amounts than IFN $\gamma$, has been developed for a simplified and more robust lateral flow test than IGRA (67). Notably, satisfactory results were obtained using dried plasma spots, amenable for conventional postal transport (68).

In view of the possibility that sequence variations in epitopic regions between clinical Mtb isolates might affect the results of IFN $\gamma$ assays, human clinical samples were sequenced to identify substitutions that may have an impact on immunogenicity. A number of sequence polymorphisms (SNPs) have been revealed in the epitope regions of EsxB and EsxH genes (69), with evidence for recombination events, which may truncate the corresponding protein. Even single-residue differences altered the responder frequencies to these antigens from $M$. bovis isolates (70). Hence, immune variation may influence the diagnostic performance of kits, which contain epitopes from the ESX proteins.

\section{T-CELL EPITOPE REPERTOIRE IN ACTIVE TB}

Commercially available IGRA assays routinely used in clinical practice do not distinguish reliably between active TB and latent infection and have limited value for predicting the risk of developing active TB (71). Therefore, it has been of interest to search, if fine analysis of epitope specificities could improve the diagnosis. Proliferation assays of blood T cells from patients with active TB recognize a smaller number of Acr epitopes than sensitized healthy subjects (Table 2) (32). Similarly, patients with leprosy recognize fewer GroEL epitopes than healthy contacts (24). These findings corroborate with the previously known skin DTH anergy to PPD in a fraction of active TB patients and with the development of leprosin anergy in multibacillary leprosy. The search for epitopes, which would distinguish patients from latent infection, yielded a promising result only for the amino-terminal peptide of GroES (1-16) (56). The selective power of this peptide is surprising, considering its overlap, except for one residue, with the $M$. leprae sequence and is in need of confirmation with more clinical samples.

A reciprocal approach to the differential diagnosis has come from the finding of selective T-cell anergy in active TB in respect of the carboxy-terminal epitope p350-369 of the PstS1 antigen, which is strongly immunogenic in latently infected subjects (31). The lack of blood T-cell response can be due to sequestration to the site of disease (e.g., pleural fluid) and the ratio of $\mathrm{T}$ cells between these compartments is influenced by chemotherapy $(72,73)$. The post-chemotherapy recovery of blood response seemed more pronounced for $\mathrm{T}$ cells reacting with the Acr peptides, than those responding to the PstS1 peptides, which could be explained by differences in expression between replicating and

\begin{tabular}{|c|c|c|c|c|}
\hline \multirow{2}{*}{$\begin{array}{l}\text { Subjects (no. tested) } \\
\text { From London }{ }^{b}\end{array}$} & \multirow{2}{*}{$\begin{array}{l}\text { Peptides } \\
\text { from } \\
\text { Acr }\end{array}$} & \multicolumn{3}{|c|}{$\begin{array}{l}\text { Frequency }(\%) \text { of } \\
\text { responders }{ }^{a}, \text { no. of } \\
\text { test peptides }(p)\end{array}$} \\
\hline & & $1-3 p$ & $4-6 p$ & $>6 p$ \\
\hline Healthy PPD+ skin test (25) & & 24 & 52 & 24 \\
\hline Active TB (38) & & 52 & 30 & 18 \\
\hline From Bangkok ${ }^{c}$ & GroES & $1-4 p$ & $5-10 p$ & $>10 p$ \\
\hline Healthy family contacts (12) & & $<1$ & 58 & 42 \\
\hline Tuberculoid leprosy (18) & & 33 & 56 & 11 \\
\hline
\end{tabular}

${ }^{a}$ Blood mononuclear cells of responders had at least threefold elevated ${ }^{3} \mathrm{H}$ thymidine uptake in cultures containing the test peptide over medium alone.Data from:

${ }^{b}$ Friscia et al. (32);

${ }^{c}$ Chua-Intra et al. (24). 
chemotherapy-generated persister organisms. While dissecting of active from latent TB T-cell repertoire merely on the grounds of epitope specificity had failed to reach consensus (72), significant differences in their cytokine secretion are represented by elevated number of polyfunctional T cells (secreting IL-2, IFN $\gamma$, and TNF $\alpha$ ) in active TB (74).

HIV-infected subjects have a high risk of reactivating their latent Mtb infection. Predicting this outcome better than just on the grounds of declining CD4 counts, would be of prime interest. The ratio of IFN $\gamma$ ELISPOT counts in response to RD-1 peptides over CD4+ T-cell counts, greater than 0.21 , showed $100 \%$ sensitivity and $80 \%$ specificity for active TB (75). However, the finding of 19\% non-responder TB patients limited the diagnostic scope of this study. PPD-stimulated T cells carry higher levels of HIV DNA and depleted sooner than T cells of other specificity (76). This could explain the frequent reactivation of latent Mtb infection in HIV+ subjects. The antigen and epitope specificities involved have not been studied much beyond the crude PPD extract and the mechanism, which renders Mtb-reactive cells more permissive to HIV infection, is not understood. One possibility could be the lower stimulatory dose of the HLA-permissive epitopes for $\mathrm{T}$ cells with high affinity TcRs. This mechanism would imply selective recognition of certain epitopes, which would be rewarding to identify in the future. So far however, attention has been directed toward the study of the CD4 T-cell phenotype, characterized as CXCR3+ CCR4+ CCR6+ CD57- IFNg+ IL-17+ IL- ${ }^{\text {hi }}$ MIP $1 b^{\text {low }}$ for the highly HIV-permissive PPD-reactive and CXCR3+ CCR4- CCR6-CD57+ IFNg+ IL-2 ${ }^{\text {low }}$ MIP1b ${ }^{\text {high }}$ for low HIV-permissive CMV and other virus-reactive T cells (76).

\section{ASSOCIATION OF HLA-DR AND ANTIBODY EPITOPE SPECIFICITY WITH TB}

Susceptibility to TB is considered to be under the influence of multiple genetic loci, including HLA alleles. HLA-DR2 was found inherited more frequently in offspring with pulmonary TB, from both diseased and healthy parents (77) and associated with sputum-positive, but not with sputum-negative active pulmonary TB (78). DR2 alleles in sputum-positive TB associated also with elevated antibody levels to two epitopes of the PstS1 lipoglycoprotein antigen (79), but not with the similarly elevated antibody levels to epitopes of three other antigens of diverse nature (Acr, 19$\mathrm{kDa}$ lipoglycoprotein, and lipoarabinomannan). The intriguing aspect of this finding is that both the genetic and immunological specificities were identified.

To explain the DR2 gene control of TB susceptibility, it has been proposed (80) that T-cell recognition of DR2-restricted PstS1 epitopes may lead to a Th2 response, producing IL-4 and IL-10 cytokines, which can lead to the development of lung pathology, rather than host protection. This hypothesis is supported by the finding, that selection of epitopes presented by B cells, rather than dendritic cells, diverted $T$ cells from protection toward pathogenicity in Leishmania infection (81). Thus, the specificity of antibody responses during active TB could guide toward antigens, containing potentially pathogenic Th2 recognized epitopes. The search for such T-cell epitopes on the PstS1 antigen so far did not yield supportive data. Epitope specificity was determined only for Th1 cell clones which were mostly HLA-DR promiscuous (82) with all immunodominant epitopes of PstS1 binding to several HLA-DR molecules (22). However, these assays may not be suitable to reveal a DR2-restricted presentation of the same epitope to Th2 T cells. Development of assays for the mapping of Th2 cell stimulatory epitopes will be important to explain the mechanism of HLA class II-mediated influences on the development of multibacillary TB.

Analysis of some of the above raised aspects had been approached in mouse experimental models. Notably, influence of $\mathrm{H}-2$ genes ( $\mathrm{Db}$ or lack of I-E expression) was observed on the late progression of intraperitoneally delivered infection and pathology in the lungs, when spleen and liver bacillary counts remained stationary (83). Though this model of selective multibacillary lung disease seems relevant, the antigen specificity of the underlying immune responses was not identified. Although antibody responses to different antigens and epitopes is under $\mathrm{H}-2 \mathrm{~A}$ control following immunization with soluble antigens in adjuvants $(84,85)$, there is no clear corresponding evidence following Mtb infection. On the other hand, antibody responses to hsp65 and hsp71 antigens (86) and liver granuloma formation (87) following $\mathrm{Mtb}$ infection were associated with non- $\mathrm{H}-2$ genes.

Further analysis of the Th2 (T-helpers for B-cell responses) epitope repertoire also needs further studies in mouse models, addressing the topographical relationship between CD4 T-cell and B-cell stimulatory epitopes (88). Though using merely proliferation assays, it appeared, that Pst $\mathrm{S} 1$ antigen immunized mice produced CD4 T cells, but not antibodies against the $\mathrm{p} 65-83$ peptide, which contains a non-overlapping cryptic B and an immunodominant T epitope core, while T-cell help was "delegated" probably to distantly located linear or conformational B-cell epitopes (Table 3) (89). A functional association between topographically distinct epitopes was suggested also by the finding that a single amino acid mutation of epitope core of the 19-kDa antigen abrogated T-cell, but not the B-cell immunogenicity (90).

\section{PEPTIDE EPITOPE-BASED VACCINATION AGAINST TB}

Most research toward a better vaccine against TB has been based on boosting immunity after BCG priming. The choice of antigen for this purpose has been to some extent subjective, though usually targeting proteins which appeared as most immunogenic in Mtb-infected individuals or experimental animals. Further breakdown of the immune repertoire to individual epitope specificities showed that both immune recognition was influenced by the nature of the immunogen. Thus, CD4 T cells recognized different peptides, when mice were vaccinated with either PstS1 antigen or heat-killed Mtb or infected with H37Rv bacilli (Table 3) (89). Antibodies reacted to different epitopes following vaccination, but bound only to conformational epitopes following infection. CD8 $\mathrm{T}$ cells also recognized different peptides following vaccination or Mtb infection $(91,92)$. These results indicate that the nature of the immunogen could influence antigen processing, which may deviate T-cell help from one to another B-cell epitope. Substantial differences in protection, cytokine profile, and recognition of T-cell epitopes of Ag85A or the Ag85B-ESAT- 6 fusion protein were observed after its presentation either expressed in adenovirus vector or with an adjuvant (93). Disparities were observed also in response to Ag85A and its immunogenic peptides, when inoculated intranasally or parenterally (94). 
Table 3 | Differences in epitope recognition between immunized and infected C57BI/10 mice.

\begin{tabular}{|c|c|c|c|c|c|c|c|}
\hline \multirow[t]{2}{*}{ Foot pad injection } & \multicolumn{4}{|c|}{$\begin{array}{l}\text { T-cell proliferation } \\
\text { to peptides }\end{array}$} & \multicolumn{3}{|c|}{$\begin{array}{l}\text { Antibody } \\
\text { level }\end{array}$} \\
\hline & $\begin{array}{l}44- \\
64\end{array}$ & $\begin{array}{l}65- \\
83\end{array}$ & $\begin{array}{l}123- \\
143\end{array}$ & $\begin{array}{l}350- \\
368\end{array}$ & $\begin{array}{l}\text { p1- } \\
20\end{array}$ & $\begin{array}{l}\text { p201- } \\
220\end{array}$ & TB71 \\
\hline Recombinant PstS1 ${ }^{a}$ & - & ++ & ++ & - & - & +++ & ++ \\
\hline Heat-killed H37Rv ${ }^{a}$ & - & - & + & + & +++ & - & + \\
\hline H37Rv infection & + & + & - & - & - & - & ++ \\
\hline
\end{tabular}

Magnitude of the immune response: stimulation indices:,$-<1 ;+, 1-10 ;++$, 10-20 of spleen and lymph node cells 7 days after immunization.

ELISA peptide binding or TB71 mAb competition titers:,$-<10 ;+, 10-100 ;++$, 100-1000; +++, > 1000 in sera harvested 12 weeks after first inoculation.

${ }^{a}$ Antigen in incomplete Freund's adjuvant followed by three boosters without adjuvant. Data from Vordermeier et al. (89).

DNA gun bombardment has been used for the mapping of T-cell epitopes and the effect of self-adjuvanting domains. Several CD4+ and one CD8+ T-cell epitopes were identified on the DNAbinding protein 1 (MDP1) antigen (95), while spleen CD4 T cells from HLA-DRB $1^{\star} 0401$ transgenic mice recognized only the p191210 epitope on the MPT51 antigen (96). A fusion DNA vaccine incorporating the HSP70 C-terminal domain (as adjuvant) and MPT51 (as target antigen) stimulated CD4, but not the CD8 Tcell response (97). Though documenting immunogenicity, these results need to be extended for protection against challenge.

Vaccine design could benefit from modifying the structure of peptides to increase their immunogenicity, while conjugation of a MHC-permissive peptide could abrogate genetic restriction for another MHC-restricted epitope. Studies in this direction showed that orientation between two epitopes within a synthetic peptide dimer can profoundly influence immunogenicity (98). Orientation of peptides played a role also for chimeric peptides constructed by recombinant DNA technology (99). Immunogenicity can be increased also by extension of an epitope core with non-native flanking residues (100) or by covalent attachment to biodegradable amphoteric branched chain polypeptides (101). Lipoylation of the MHC-promiscuous 91-110 peptide of Acr inoculated without any adjuvants was reported to enhance the immunogenicity and imparted protection against aerosol Mtb challenge in both mice and guinea pigs to an even better extent than BCG (102).

\section{EPITOPE-SPECIFIC SERODIAGNOSIS}

Mycobacterium tuberculosis species-specific mAbs had been used in a competition serodiagnostic test for TB and leprosy, preceding the purification of target antigens $(103,104)$. The mAb competition test has the advantage of higher sensitivity due to its low background values, which allowed the use of 20 times lower serum dilutions (i.e., 1/5) than standard ELISA tests (1/100). The competition assay also discriminated species-specific from cross-reactive epitopes on a number of antigens and identified several associations between antibody specificity and clinical aspects of TB $(105,106)$ (see also chapter by G. Bothamley). Epitope-specific antibody levels can be representative for both specificity and sensitivity of the whole antigen (e.g., PstS1) (51). However, the mAb competition test was more specific than binding to the whole lipoarabinomann, by targeting a Mtb-specific epitope or avoiding detection of contaminants. Epitope-specific titers also reflected the clinical form of $\mathrm{TB}$, when related to titers against the whole 19-kDa lipoprotein (107).

Several serological surveys showed that serum antibody levels are consistently elevated in the great majority of sputum-positive TB, but not in sputum-negative disease (108). Though the latter aspect is greatly limiting the diagnostic application of serology, this hindrance was not acknowledged during the uncontrolled marketing of commercial kits. On the other hand, detection of antibodies in the cerebrospinal fluid is of particular value for the diagnosis of TB meningitis (109), where rapid detection can be life saving. Due to the high sensitivity, low cost, and operational advantages, serological screening has been suggested for active case finding in highrisk populations for multibacillary infectious patients $(108,110)$. Their early diagnosis could reduce the transmission of Mtb infection and therefore represents an important epidemiological, rather than clinical objective. A similar rationale could apply to leprosy, where antibody levels are elevated in the infectious multibacillary lepromatous, rather than the paucibacillary tuberculoid form (3).

A recent advance in epitope screening has been the high-content peptide microarray chip technology, involving the testing of thousands of different peptides. This approach showed that several epitopes are differentially recognized by IgG antibodies in pulmonary TB sera (111) and identified epitope "hotspots" within a number of protein antigens with similar patterns for patients of different genetic background. These linear epitopes are likely to detect a different repertoire than serology based on whole protein molecules, which detects mostly antibodies against conformational epitopes. Further clinical evaluation, particularly comparing multi- and paucibacillary forms of active TB, seems warranted.

\section{TcR-LIKE LIGANDS}

Tubercle bacilli multiply and persist predominantly in macrophages, which display on their surface HLA-bound antigenic mycobacterial peptides, which are recognized by T-cell receptors (TcR). T cells can impart protection, but their excessive reactions can lead also to inflammatory pathology, characteristic of active TB. To avoid the latter outcome, suitable T-cell receptor-like constructs could be protective, without the accompanying undesirable T-cell-mediated inflammation. Immunotherapy using soluble TcR ligands could kill macrophages infected with both replicating and dormant $\mathrm{Mtb}$ organisms. Based on this hypothesis, TcR-based immunotherapy could be used as an adjunct to chemotherapy and be particularly useful to HIV-infected TB patients, many of whom being immunocompromised, cannot be protected by active vaccination. Therefore, TcR immunotherapy might be better than "therapeutic" active vaccination and also more efficient than passive antibody therapy, which can target probably only extracellular Mtb bacilli $(112,113)$. Unlike antibodies to B-cell epitopes [including those directed against overlapping T and B epitopes (114)], TcR-like ligands would be directed against epitopes, displayed in complex with MHC molecules on the surface of Mtb-infected cells. 
Development of immunotherapeutic agents with TcR specificity has become feasible with the introduction of two technologies: (1) single chain antibody fragments ( $\mathrm{scFv}$ ) with $\mathrm{TcR}$ specificity can be selected from phage antibody libraries (115118); (2) monomeric high affinity soluble human TcRs (mTcRs) have been expressed from cloned CD8 T cells and produced within the cytoplasm of trxB gor mutant E. coli strains (119). TcR-like mAbs against HLA class I presented epitopes of tumors (120) and virus-infected cells are being developed as novel immunotherapeutics with epitope-specific killing potentials, as well as diagnostic reagents (118). Moreover, genetic fusion of Pseudomonas exotoxin with TcR-like mAbs amplified the killing tumor cells $(121,122)$.

These advances, particularly in epitope-specific cancer immunotherapy, seem attractive for the development of TB immunotherapy. Production of $\mathrm{mAb}$ and $\mathrm{mTcR}$ ligands needs to target some of the empirically identified HLA class I immunodominant epitopes, which have been mapped for a number of $\mathrm{Mtb}$ antigens $(26,33,34,91,123,124)$. However, a similar approach to MHC class II-presented epitopes could be much more difficult, because their expression is impaired in infected macrophages (125) and because the procedures for producing the corresponding TcR-like ligands are yet underdeveloped. However, some concerns need to be addressed: immunodominance of the currently known MHC class I epitopes may have resulted from peptide presentation by dendritic cells or by cross-presentation, while a TcRbased immunotherapy would need to be targeted against epitopes expressed by infected macrophages. Therefore, it is a prerequisite to confirm the specificity and density of epitope expression on Mtb-infected macrophages. This needs to be ascertained by their capacity to stimulate CD8 T-cell clones or better by direct detection of the levels of epitope expression by antibody staining (126), or by tandem mass spectrometry (127). Notably, the latter technique showed that epitope abundance does not necessarily associate with the immunodominance hierarchy of epitopes.

Since apoptosis of macrophages is known to be the key mechanism for the killing of intracellular mycobacteria $(128,129)$, conjugation of TcR-specific ligands with apoptosis-inducing agents may amplify the therapeutic effect. Suitable candidate compounds for this purpose, with proven apoptosis-inducing capacity are Pseudomonas exotoxin A (130), granzyme B $(131,132)$, or BH3 peptide $(133,134)$.

Further synergistic benefit may come from recombinant INF $\gamma$ treatment, which enhances the surface expression of MHC-bound epitopes and has even alone been therapeutically beneficial in TB patients (135).

\section{TREGITOPES}

Tregitopes are epitopes, mostly in the Fc and constant Fab region of IgG, with highly conserved structure between mammalian species. They bind promiscuously to HLA class II molecules and stimulate and expand CD25(+) FoxP3(+) natural regulatory T cells (nTreg) (136). Tregitopes were shown to inhibit CD8 T-cell responses to co-administered antigens, with potentials to prevent or treat autoimmune disease, e.g., Type 1 diabetes or suppress allo-specific responses in mouse models. Co-administration of Tregitopes and auto-antigens reduced diabetes in NOD mice, while the in vitro response of $\mathrm{T}$ cells from diabetic patients to GAD65 epitopes was found suppressed by Tregitopes (137). Tregitopes might also prevent immune responses against hyper-variable Ig Ids, generated by somatic mutations.

The long-known therapeutic effects of intravenous human gamma globulin therapy (ivG) in autoimmune or allergic diseases, organ transplantation, and graft-versus-host disease have been attributed to the presence of Tregitopes in IgG $(136,138)$. The proposed mechanism as ivG-induced immunological tolerance has been supported by the increase of Treg cells and IL-10 production after ivG treatment. This concept is relevant to TB, considering the finding that intranasal or intraperitoneal inoculations of human gamma globulin inhibited the BCG viable counts in the lungs of intranasally infected mice $(139,140)$. Although the authors attributed this effect to the action of specific antibodies, an alternative possible explanation could involve the role of Tregitopes.

Increased Treg numbers in patients with active TB depress the IFN $\gamma$-secreting T-cell response to a protective antigen, such as the heparin binding hemagglutinin (141). Mycobacterium-activated human CD8 Treg cells co-express CD39, which is involved in the suppression of CD4 Th1 cell proliferation, lymphocyte activation, and express also LAG-3 and CCL4 (142). Impairing the function of Tregs in mice reduced Mtb infection (143), but antibody inactivation of Tregs, which increased the immune response did not affect the bacterial load after infection (144) and did not influence protection by BCG vaccination (145). In view of these discrepancies about the possible Treg function in TB and the lack of knowledge about their specificity, the possible role of Tregitope recognition deserves further study.

\section{CONCLUSION}

Epitope specificity of immune responses of Mtb-infected hosts is significant for the immunopathogenesis of TB and its knowledge is mandatory for the development of new approaches toward TB control. HLA-permissive epitopes may have evolved in the tubercle bacilli due to the advantage from immune reactions, which lead to protracted transmission of the infection. Further research needs to expand knowledge on associations between epitope specificity with different effector and regulatory T-cell populations. It is proposed that combining of the biosignature of the T-cell phenotype with epitope specificity might lead to the discovery of protection and disease-associated biomarkers. There are important potentials toward the future development of epitope-defined diagnostics, prophylactic vaccines, and immunotherapies.

\section{ACKNOWLEDGMENTS}

I thank for collaboration all co-authors, quoted in the several joint publications.

\section{REFERENCES}

1. Ivanyi J. Pathogenic and protective interactions in mycobacterial infections. Clin Immunol (1986) 6:127-57.

2. Ivanyi J, Morris JA, Keen M. Studies with monoclonal antibodies to mycobacteria. In: Macario AJL, Macario EC, editors. Monoclonal Antibodies Against Bacteria. New York: Academic Press (1985). p. 59-90.

3. Ivanyi J, Sharp K, Jackett P, Bothamley G. Immunological study of the defined constituents of mycobacteria. Springer Semin Immunopathol (1988) 10:279-300. doi:10.1007/BF02053841 
4. Young RA, Bloom BR, Grosskinsky CM, Ivanyi J, Thomas D, Davis RW. Dissection of Mycobacterium tuberculosis antigens using recombinant DNA. Proc Natl Acad Sci U S A (1985) 82:2583-7. doi:10.1073/pnas.82.9.2583

5. Lamb JR, Ivanyi J, Rees AD, Rothbard JB, Howland K, Young RA, et al. Mapping of $\mathrm{T}$ cell epitopes using recombinant antigens and synthetic peptides. EMBO J (1987) 6:1245-9.

6. McMurry JA, Kimball S, Lee JH, Rivera D, Martin W, Weiner DB, et al. Epitopedriven TB vaccine development: a streamlined approach using immunoinformatics, ELISpot assays, and HLA transgenic mice. Curr Mol Med (2007) 7:351-68. doi:10.2174/156652407780831584

7. Vordermeier M, Whelan AO, Hewinson RG. Recognition of mycobacterial epitopes by $\mathrm{T}$ cells across mammalian species and use of a program that predicts human HLA-DR binding peptides to predict bovine epitopes. Infect Immun (2003) 71:1980-7. doi:10.1128/IAI.71.4.1980-1987.2003

8. Scarabelli G, Morra G, Colombo G. Predicting interaction sites from the energetics of isolated proteins: a new approach to epitope mapping. Biophys J (2010) 98:1966-75. doi:10.1016/j.bpj.2010.01.014

9. Berry MP, Blankley S, Graham CM, Bloom CI, O'Garra A. Systems approaches to studying the immune response in tuberculosis. Curr Opin Immunol (2013) 25:579-87. doi:10.1016/j.coi.2013.08.003

10. Ernst JD, Lewinsohn DM, Behar S, Blythe M, Schlesinger LS, Kornfeld H, et al. Meeting report: NIH workshop on the tuberculosis immune epitope database. Tuberculosis (Edinb) (2008) 88:366-70. doi:10.1016/j.tube.2007.11.002

11. Lindestam Arlehamn CS, Gerasimova A, Mele F, Henderson R, Swann J, Greenbaum JA, et al. Memory $\mathrm{T}$ cells in latent Mycobacterium tuberculosis infection are directed against three antigenic islands and largely contained in a CXCR3+CCR6+ Th1 subset. PLoS Pathog (2013) 9:e1003130. doi:10.1371/journal.ppat.1003130

12. Axelsson-Robertson R, Magalhaes I, Parida SK, Zumla A, Maeurer M. The immunological footprint of Mycobacterium tuberculosis T-cell epitope recognition. J Infect Dis (2012) 205(Suppl 2):S301-15. doi:10.1093/infdis/jis198

13. Brett SJ, Lamb JR, Cox JH, Rothbard JB, Mehlert A, Ivanyi J. Differential pattern of $\mathrm{T}$ cell recognition of the $65-\mathrm{kDa}$ mycobacterial antigen following immunization with the whole protein or peptides. Eur J Immunol (1989) 19:1303-10. doi:10.1002/eji.1830190723

14. Vordemeier HM, Harris DP, Roman E, Lathigra R, Moreno C, Ivanyi J. Identification of T cell stimulatory peptides from the 38-kDa protein of Mycobacterium tuberculosis. J Immunol (1991) 147:1023-9.

15. Harris DP, Vordermeier HM, Friscia G, Roman E, Surcel HM, Pasvol G, et al. Genetically permissive recognition of adjacent epitopes from the $19-\mathrm{kDa}$ antigen of Mycobacterium tuberculosis by human and murine T cells. J Immunol (1993) 150:5041-50.

16. Vordermeier HM, Harris DP, Lathigra R, Roman E, Moreno C, Ivanyi J. Recognition of peptide epitopes of the 16,000 MW antigen of Mycobacterium tuberculosis by murine T cells. Immunology (1993) 80:6-12.

17. Vordermeier HM, Arya A, Harris DP, Moreno C, Ivanyi J. Abundance of H2 promiscuous $\mathrm{T}$ cells specific for mycobacterial determinants in $\mathrm{H}-2 \mathrm{~b} / \mathrm{d}$ F1 hybrid mice. Eur J Immunol (1995) 25:2770-4. doi:10.1002/eji.1830251009

18. Harris DP, Vordermeier HM, Arya A, Moreno C, Ivanyi J. Permissive recognition of a mycobacterial T-cell epitope: localization of overlapping epitope core sequences recognized in association with multiple major histocompatibility complex class II I-A molecules. Immunology (1995) 84:555-61.

19. Roman E, Harris DP, Jurcevic S, Ivanyi J, Moreno C. H-2-associated effects of flanking residues on the recognition of a permissive mycobacterial T-cell epitope. Immunology (1995) 86:183-9.

20. Agrewala JN, Wilkinson RJ. Influence of HLA-DR on the phenotype of CD4+ $\mathrm{T}$ lymphocytes specific for an epitope of the $16-\mathrm{kDa}$ alpha-crystallin antigen of Mycobacterium tuberculosis. Eur J Immunol (1999) 29:1753-61. doi:10.1002/ (SICI) 1521-4141(199906)29:06<753::AID-IMMU1753>3.0.CO;2-B

21. Comas I, Chakravartti J, Small PM, Galagan J, Niemann S, Kremer K, et al. Human T cell epitopes of Mycobacterium tuberculosis are evolutionarily hyperconserved. Nat Genet (2010) 42:498-503. doi:10.1038/ng.590

22. Jurcevic S, Hills A, Pasvol G, Davidson RN, Ivanyi J, Wilkinson RJ. T cell responses to a mixture of Mycobacterium tuberculosis peptides with complementary HLA-DR binding profiles. Clin Exp Immunol (1996) 105:416-21. doi:10.1046/j.1365-2249.1996.d01-791.x

23. Mustafa AS, Lundin KE, Meloen RH, Shinnick TM, Oftung F. Identification of promiscuous epitopes from the mycobacterial 65-kilodalton heat shock protein recognized by human CD4(+) T cells of the Mycobacterium leprae memory repertoire. Infect Immun (1999) 67:5683-9.

24. Chua-Intra B, Peerapakorn S, Davey N, Jurcevic S, Busson M, Vordermeier $\mathrm{HM}$, et al. T-cell recognition of mycobacterial GroES peptides in Thai leprosy patients and contacts. Infect Immun (1998) 66:4903-9.

25. Caccamo N, Barera A, Di Sano C, Meraviglia S, Ivanyi J, Hudecz F, et al. Cytokine profile, HLA restriction and TCR sequence analysis of human CD4+ T clones specific for an immunodominant epitope of Mycobacterium tuberculosis 16kDa protein. Clin Exp Immunol (2003) 133:260-6. doi:10.1046/j.1365-2249. 2003.02201.x

26. Shams H, Klucar P, Weis SE, Lalvani A, Moonan PK, Safi H, et al. Characterization of a Mycobacterium tuberculosis peptide that is recognized by human CD4+ and CD8+ T cells in the context of multiple HLA alleles. J Immunol (2004) 173:1966-77.

27. Tully G, Kortsik C, Hohn H, Zehbe I, Hitzler WE, Neukirch C, et al. Highly focused $\mathrm{T}$ cell responses in latent human pulmonary Mycobacterium tuberculosis infection. J Immunol (2005) 174:2174-84.

28. Valle MT, Megiovanni AM, Merlo A, Li Pira G, Bottone L, Angelini G, et al. Epitope focus, clonal composition and Th1 phenotype of the human CD4 response to the secretory mycobacterial antigen Ag85. Clin Exp Immunol (2001) 123:226-32. doi:10.1046/j.1365-2249.2001.01450.x

29. Al-Attiyah R, Shaban FA, Wiker HG, Oftung F, Mustafa AS. Synthetic peptides identify promiscuous human Thl cell epitopes of the secreted mycobacterial antigen MPB70. Infect Immun (2003) 71:1953-60. doi:10.1128/IAI.71.4.19531960.2003

30. Wang M, Tang ST, Stryhn A, Justesen S, Larsen MV, Dziegiel MH, et al. Identification of MHC class II restricted T-cell-mediated reactivity against MHC class I binding Mycobacterium tuberculosis peptides. Immunology (2011) 132:482-91. doi:10.1111/j.1365-2567.2010.03383.x

31. Vordermeier HM, Harris DP, Friscia G, Roman E, Surcel HM, Moreno C, et al. T cell repertoire in tuberculosis: selective anergy to an immunodominant epitope of the $38-\mathrm{kDa}$ antigen in patients with active disease. Eur J Immunol (1992) 22:2631-7. doi:10.1002/eji.1830221024

32. Friscia G, Vordermeier HM, Pasvol G, Harris DP, Moreno C, Ivanyi J. Human T cell responses to peptide epitopes of the $16-\mathrm{kD}$ antigen in tuberculosis. Clin Exp Immunol (1995) 102:53-7. doi:10.1111/j.1365-2249.1995.tb06635.x

33. Weichold FF, Mueller S, Kortsik C, Hitzler WE, Wulf MJ, Hone DM, et al. Impact of MHC class I alleles on the M. tuberculosis antigen-specific CD8+ T-cell response in patients with pulmonary tuberculosis. Genes Immun (2007) 8:334-43. doi:10.1038/sj.gene.6364392

34. Axelsson-Robertson R, Weichold F, Sizemore D, Wulf M, Skeiky YA, Sadoff J, et al. Extensive major histocompatibility complex class I binding promiscuity for Mycobacterium tuberculosis TB10.4 peptides and immune dominance of human leucocyte antigen (HLA)-B ${ }^{\star} 0702$ and HLA-B ${ }^{\star} 0801$ alleles in TB10.4 CD8 T-cell responses. Immunology (2010) 129:496-505. doi:10.1111/j.13652567.2009.03201.x

35. Jurcevic S, Travers PJ, Hills A, Agrewala JN, Moreno C, Ivanyi J. Distinct conformations of a peptide bound to HLA-DR1 or DRB5 ${ }^{\star} 0101$ suggested by molecular modelling. Int Immunol (1996) 8:1807-14. doi:10.1093/intimm/8. 11.1807

36. Caccamo N, Meraviglia S, La Mendola C, Bosze S, Hudecz F, Ivanyi J, et al. Characterization of HLA-DR- and TCR-binding residues of an immunodominant and genetically permissive peptide of the $16-\mathrm{kDa}$ protein of Mycobacterium tuberculosis. Eur J Immunol (2004) 34:2220-9. doi:10.1002/eji.200425090

37. Sundaramurthi JC, Brindha S, Shobitha SR, Swathi A, Ramanandan P, Hanna LE. In silico identification of potential antigenic proteins and promiscuous CTL epitopes in Mycobacterium tuberculosis. Infect Genet Evol (2012) 12:1312-8. doi:10.1016/j.meegid.2012.03.023

38. Bobosha K, Tang ST, van der Ploeg-van Schip JJ, Bekele Y, Martins MV, Lund $\mathrm{O}$, et al. Mycobacterium leprae virulence-associated peptides are indicators of exposure to M. leprae in Brazil, Ethiopia and Nepal. Mem Inst Oswaldo Cruz (2012) 107(Suppl 1):112-23. doi:10.1590/S0074-02762012000900018

39. Wiens KE, Swaminathan H, Copin R, Lun DS, Ernst JD. Equivalent T cell epitope promiscuity in ecologically diverse human pathogens. PLoS One (2013) 8:e73124. doi:10.1371/journal.pone.0073124

40. Ivanyi J, Norton PM, Matsuzaki G. Immune responses to stress proteins in mycobacterial infections. In: van Eden W, Young DB, editors. Stress Proteins in Medicine. New York: Marcel Dekker, Inc. (1996). p. 265-285. 
41. Kiessling R, Gronberg A, Ivanyi J, Soderstrom K, Ferm M, Kleinau S, et al. Role of hsp60 during autoimmune and bacterial inflammation. Immunol Rev (1991) 121:91-111. doi:10.1111/j.1600-065X.1991.tb00824.x

42. Wick G, Kleindienst R, Schett G, Amberger A, Xu Q. Role of heat shock protein 65/60 in the pathogenesis of atherosclerosis. Int Arch Allergy Immunol (1995) 107:130-1. doi:10.1159/000236952

43. Van Eden W, Wick G, Albani S, Cohen I. Stress, heat shock proteins, and autoimmunity: how immune responses to heat shock proteins are to be used for the control of chronic inflammatory diseases. Ann N Y Acad Sci (2007) 1113:217-37. doi:10.1196/annals.1391.020

44. Grundtman C, Kreutmayer SB, Almanzar G, Wick MC, Wick G. Heat shock protein 60 and immune inflammatory responses in atherosclerosis. Arterioscler Thromb Vasc Biol (2011) 31:960-8. doi:10.1161/ATVBAHA.110.217877

45. Raine CS, Wu E, Ivanyi J, Katz D, Brosnan CF. Multiple sclerosis: a protective or a pathogenic role for heat shock protein 60 in the central nervous system? Lab Invest (1996) 75:109-23.

46. Spencer JS, Marques MA, Lima MC, Junqueira-Kipnis AP, Gregory BC, Truman RW, et al. Antigenic specificity of the Mycobacterium leprae homologue of ESAT-6. Infect Immun (2002) 70:1010-3. doi:10.1128/IAI.70.2.1010-1013.2002

47. Ivanyi J. Recall of antibody synthesis to the primary antigen following successive immunization with heterologous albumins. A two-cell theory of the original antigenic sin. Eur J Immunol (1972) 2:354-9. doi:10.1002/eji.1830020411

48. Bothamley G, Beck JS, Britton W, Elsaghier A, Ivanyi J. Antibodies to Mycobacterium tuberculosis-specific epitopes in lepromatous leprosy. Clin Exp Immunol (1991) 86:426-32. doi:10.1111/j.1365-2249.1991.tb02948.x

49. Harris DP, Vordermeier HM, Singh M, Moreno C, Jurcevic S, Ivanyi J. Crossrecognition by $\mathrm{T}$ cells of an epitope shared by two unrelated mycobacterial antigens. Eur J Immunol (1995) 25:3173-9. doi:10.1002/eji.1830251128

50. Harris DP, Vordermeier HM, Roman E, Lathigra R, Brett SJ, Moreno C, et al. Murine T cell-stimulatory peptides from the 19-kDa antigen of Mycobacterium tuberculosis. Epitope-restricted homology with the 28-kDa protein of Mycobacterium leprae. J Immunol (1991) 147:2706-12.

51. Jackett PS, Bothamley GH, Batra HV, Mistry A, Young DB, Ivanyi J. Specificity of antibodies to immunodominant mycobacterial antigens in pulmonary tuberculosis. J Clin Microbiol (1988) 26:2313-8.

52. Elsaghier A, Lathigra R, Ivanyi J. Localisation of linear epitopes at the carboxyterminal end of the mycobacterial $71 \mathrm{kDa}$ heat shock protein. Mol Immunol (1992) 29:1153-6. doi:10.1016/0161-5890(92)90049-4

53. Elsaghier A, Prantera C, Bothamley G, Wilkins E, Jindal S, Ivanyi J. Disease association of antibodies to human and mycobacterial hsp70 and hsp60 stress proteins. Clin Exp Immunol (1992) 89:305-9. doi:10.1111/j.1365-2249.1992. tb06950.x

54. Elsaghier A, Prantera C, Moreno C, Ivanyi J. Antibodies to Mycobacterium paratuberculosis-specific protein antigens in Crohn's disease. Clin Exp Immunol (1992) 90:503-8. doi:10.1111/j.1365-2249.1992.tb05874.x

55. Chua-Intra B, Ivanyi J, Hills A, Thole J, Moreno C, Vordermeier HM. Predominant recognition of species-specific determinants of the GroES homologues from Mycobacterium leprae and M. tuberculosis. Immunology (1998) 93:64-72. doi:10.1046/j.1365-2567.1998.00400.x

56. Chua-Intra B, Wilkinson RJ, Ivanyi J. Selective T-cell recognition of the Nterminal peptide of GroES in tuberculosis. Infect Immun (2002) 70:1645-7. doi:10.1128/IAI.70.3.1645-1647.2002

57. Chua-Intra B, Wattanapokayakit S, Srisungngam S, Srisungngam T, Mahotarn $\mathrm{K}$, Brennan PJ, et al. T-cell recognition of peptides from the Mycobacterium leprae $35 \mathrm{kDa}$ protein in Thai leprosy patients, healthy contacts, and non-contacts. Immunol Lett (2003) 88:71-6. doi:10.1016/S0165-2478(03)00065-8

58. Kaleab B, Wondimu A, Likassa R, Woldehawariat N, Ivanyi J. Sustained Tcell reactivity to Mycobacterium tuberculosis specific antigens in "split-anergic" leprosy. Lepr Rev (1995) 66:19-25.

59. Praputpittaya K, Ivanyi J. Stimulation by anti-idiotype antibody of murine T cell responses to the $38 \mathrm{kD}$ antigen of Mycobacterium tuberculosis. Clin Exp Immunol (1987) 70:307-15.

60. Rees AD, Scoging A, Dobson N, Praputpittaya K, Young D, Ivanyi J, et al. T cell activation by anti-idiotypic antibody: mechanism of interaction with antigenreactive T cells. Eur J Immunol (1987) 17:197-201. doi:10.1002/eji.1830170208

61. Mackworth-Young CG, Cairns E, Sabbaga J, Massicotte H, Diamond B, Bell DA, et al. Comparative study of idiotypes on monoclonal antibodies derived from patients with lupus and leprosy and from normal individuals. J Autoimmun (1990) 3:415-29. doi:10.1016/S0896-8411(05)80009-5
62. Zumla A, Williams W, Mudd D, Locniskar M, Behrens R, Isenberg D, et al. Expression of a common idiotype PR4 in the sera of patients with leprosy. Clin Exp Immunol (1991) 84:522-6.

63. Arlehamn CS, Sidney J, Henderson R, Greenbaum JA, James EA, Moutaftsi M, et al. Dissecting mechanisms of immunodominance to the common tuberculosis antigens ESAT-6, CFP10, Rv2031c (hspX), Rv2654c (TB7.7), and Rv1038c (EsxJ). J Immunol (2012) 188:5020-31. doi:10.4049/jimmunol.1103556

64. Flores-Villalva S, Suarez-Guemes F, Espitia C, Whelan AO, Vordermeier M, Gutierrez-Pabello JA. Specificity of the tuberculin skin test is modified by use of a protein cocktail containing ESAT- 6 and CFP-10 in cattle naturally infected with Mycobacterium bovis. Clin Vaccine Immunol (2012) 19:797-803. doi:10.1128/CVI.05668-11

65. Casal C, Bezos J, Diez-Guerrier A, Alvarez J, Romero B, de Juan L, et al. Evaluation of two cocktails containing ESAT-6, CFP-10 and Rv-3615c in the intradermal test and the interferon-gamma assay for diagnosis of bovine tuberculosis. Prev Vet Med (2012) 105:149-54. doi:10.1016/j.prevetmed.2012.02.007

66. Saleem IY, Vordermeier M, Barralet JE, Coombes AG. Improving peptide-based assays to differentiate between vaccination and Mycobacterium bovis infection in cattle using nanoparticle carriers for adsorbed antigens. J Control Release (2005) 102:551-61. doi:10.1016/j.jconrel.2004.10.034

67. Ruhwald M, Aabye MG, Ravn P. IP-10 release assays in the diagnosis of tuberculosis infection: current status and future directions. Expert Rev Mol Diagn (2012) 12:175-87. doi:10.1586/erm.11.97

68. Aabye MG, Latorre I, Diaz J, Maldonado J, Mialdea I, Eugen-Olsen J, et al. Dried plasma spots in the diagnosis of tuberculosis: IP-10 release assay on filter paper. Eur Respir J (2013) 42:495-503. doi:10.1183/09031936.00129412

69. Uplekar S, Heym B, Friocourt V, Rougemont J, Cole ST. Comparative genomics of Esx genes from clinical isolates of Mycobacterium tuberculosis provides evidence for gene conversion and epitope variation. Infect Immun (2011) 79:4042-9. doi:10.1128/IAI.05344-11

70. Jones GJ, Gordon SV, Hewinson RG, Vordermeier HM. Screening of predicted secreted antigens from Mycobacterium bovis reveals the immunodominance of the ESAT-6 protein family. Infect Immun (2010) 78:1326-32. doi:10.1128/IAI.01246-09

71. Chegou NN, Heyckendorf J, Walzl G, Lange C, Ruhwald M. Beyond the IFNgamma horizon: biomarkers for immunodiagnosis of infection with M. tuberculosis. Eur Respir J (2013). doi:10.1183/09031936.00151413

72. Wilkinson RJ, Vordermeier HM, Wilkinson KA, Sjolund A, Moreno C, Pasvol $\mathrm{G}$, et al. Peptide-specific T cell response to Mycobacterium tuberculosis: clinical spectrum, compartmentalization, and effect of chemotherapy. J Infect Dis (1998) 178:760-8. doi:10.1086/515336

73. Dieli F, Friscia G, Di Sano C, Ivanyi J, Singh M, Spallek R, et al. Sequestration of $\mathrm{T}$ lymphocytes to body fluids in tuberculosis: reversal of anergy following chemotherapy. J Infect Dis (1999) 180:225-8. doi:10.1086/314852

74. Caccamo N, Dieli F. Are polyfunctional cells protective in M. tuberculosis infection? In: Cardona P-J, editor. Understanding Tuberculosis-Analyzing the Origin of Mycobacterium tuberculosis Pathogenicity. Rieka: InTech (2012). p. 313-42.

75. Goletti D, Carrara S, Mayanja-Kizza H, Baseke J, Mugerwa MA, Girardi E, et al. Response to M. tuberculosis selected RD1 peptides in Ugandan HIV-infected patients with smear positive pulmonary tuberculosis: a pilot study. BMC Infect Dis (2008) 8:11. doi:10.1186/1471-2334-8-11

76. Geldmacher C, Ngwenyama N, Schuetz A, Petrovas C, Reither K, Heeregrave EJ, et al. Preferential infection and depletion of Mycobacterium tuberculosisspecific CD4 T cells after HIV-1 infection. J Exp Med (2010) 207:2869-81. doi:10.1084/jem.20100090

77. Singh SP, Mehra NK, Dingley HB, Pande JN, Vaidya MC. Human leukocyte antigen (HLA)-linked control of susceptibility to pulmonary tuberculosis and association with HLA-DR types. J Infect Dis (1983) 148:676-81. doi:10.1093/infdis/148.4.676

78. Brahmajothi V, Pitchappan RM, Kakkanaiah VN, Sashidhar M, Rajaram K, Ramu S, et al. Association of pulmonary tuberculosis and HLA in south India. Tubercle (1991) 72:123-32. doi:10.1016/0041-3879(91)90039-U

79. Bothamley GH, Beck JS, Schreuder GM, D’Amaro J, de Vries RR, Kardjito T, et al. Association of tuberculosis and M. tuberculosis-specific antibody levels with HLA. J Infect Dis (1989) 159:549-55. doi:10.1093/infdis/159.3.549

80. Ivanyi J, Thole J. Specificity and function of T and B cell recognition in tuberculosis. In: Bloom BR, editor. Tuberculosis: Pathogenesis, Protection and Control. Washington, DC: ASM Press (1994). p. 437-58. 
81. Rossi-Bergmann B, Muller I, Godinho EB. TH1 and TH2 T-cell subsets are differentially activated by macrophages and B cells in murine leishmaniasis. Infect Immun (1993) 61:2266-9.

82. Pitchappan RM, Agrewala JN, Dheenadhayalan V, Ivanyi J. Major histocompatibility complex restriction in tuberculosis susceptibility. J Biosci (1997) 22:47-57. doi:10.1007/BF02703617

83. Brett S, Orrell JM, Swanson Beck J, Ivanyi J. Influence of $\mathrm{H}-2$ genes on growth of Mycobacterium tuberculosis in the lungs of chronically infected mice. Immunology (1992) 76:129-32.

84. Ivanyi J, Sharp K. Control by H-2 genes of murine antibody responses to protein antigens of Mycobacterium tuberculosis. Immunology (1986) 59:329-32.

85. Barcenas-Morales G, Merkenschlager M, Wahid F, Doffinger R, Ivanyi J. Recessive expression of the $\mathrm{H} 2 \mathrm{~A}$-controlled immune response phenotype depends critically on antigen dose. Immunology (2000) 99:221-8. doi:10.1046/j.13652567.2000.00956.x

86. Brett SJ, Ivanyi J. Genetic influences on the immune repertoire following tuberculous infection in mice. Immunology (1990) 71:113-9.

87. Orrell JM, Brett SJ, Ivanyi J, Coghill G, Grant A, Beck JS. Morphometric analysis of Mycobacterium tuberculosis infection in mice suggests a genetic influence on the generation of the granulomatous inflammatory response. J Pathol (1992) 166:77-82. doi:10.1002/path.1711660112

88. Verbon A, Hartskeerl RA, Moreno C, Kolk AH. Characterization of B cell epitopes on the $16 \mathrm{~K}$ antigen of Mycobacterium tuberculosis. Clin Exp Immunol (1992) 89:395-401. doi:10.1111/j.1365-2249.1992.tb06969.x

89. Vordermeier HM, Harris DP, Moreno C, Singh M, Ivanyi J. The nature of the immunogen determines the specificity of antibodies and $\mathrm{T}$ cells to selected peptides of the $38 \mathrm{kDa}$ mycobacterial antigen. Int Immunol (1995) 7:559-66. doi:10.1093/intimm/7.4.559

90. Harris DP, Hill M, Vordermeier HM, Jones M, Hewinson G, Thangaraj H, et al. Mutagenesis of an immunodominant $\mathrm{T}$ cell epitope can affect recognition of different $\mathrm{T}$ and B determinants within the same antigen. Mol Immunol (1997) 34:315-22. doi:10.1016/S0161-5890(97)00041-2

91. Zhu X, Stauss HJ, Ivanyi J, Vordermeier HM. Specificity of CD8+ T cells from subunit-vaccinated and infected $\mathrm{H}-2 \mathrm{~b}$ mice recognizing the $38 \mathrm{kDa}$ antigen of Mycobacterium tuberculosis. Int Immunol (1997) 9:1669-76. doi:10.1093/ intimm/9.11.1669

92. Zhu X, Venkataprasad N, Thangaraj HS, Hill M, Singh M, Ivanyi J, et al. Functions and specificity of $\mathrm{T}$ cells following nucleic acid vaccination of mice against Mycobacterium tuberculosis infection. J Immunol (1997) 158:5921-6.

93. Bennekov T, Dietrich J, Rosenkrands I, Stryhn A, Doherty TM, Andersen P. Alteration of epitope recognition pattern in Ag85B and ESAT-6 has a profound influence on vaccine-induced protection against Mycobacterium tuberculosis. Eur J Immunol (2006) 36:3346-55. doi:10.1002/eji.200636128

94. Tchilian E, Ahuja D, Hey A, Jiang S, Beverley P. Immunization with different formulations of Mycobacterium tuberculosis antigen 85A induces immune responses with different specificity and protective efficacy. Vaccine (2013) 31:4624-31. doi:10.1016/j.vaccine.2013.07.040

95. Suzuki D, Nagata T, Eweda G, Matsumoto S, Matsumoto M, Tsujimura K, et al. Characterization of murine T-cell epitopes on mycobacterial DNAbinding protein 1 (MDP1) using DNA vaccination. Vaccine (2010) 28:2020-5. doi:10.1016/j.vaccine.2009.10.062

96. Wang LX, Nagata T, Tsujimura K, Uchijima M, Seto S, Koide Y. Identification of HLA-DR4-restricted T-cell epitope on MPT51 protein, a major secreted protein derived from Mycobacterium tuberculosis using MPT51 overlapping peptides screening and DNA vaccination. Vaccine (2010) 28:2026-31. doi:10.1016/j.vaccine.2009.10.063

97. Uto T, Tsujimura K, Uchijima M, Seto S, Nagata T, Suda T, et al. A novel vaccine strategy to induce mycobacterial antigen-specific Th1 responses by utilizing the C-terminal domain of heat shock protein 70. FEMS Immunol Med Microbiol (2011) 61:189-96. doi:10.1111/j.1574-695X.2010.00762.x

98. Cox JH, Ivanyi J, Young DB, Lamb JR, Syred AD, Francis MJ. Orientation of epitopes influences the immunogenicity of synthetic peptide dimers. Eur J Immunol (1988) 18:2015-9. doi:10.1002/eji.1830181222

99. De Smet KA, Vordermeier HM, Ivanyi J. A versatile system for the production of recombinant chimeric peptides. J Immunol Methods (1994) 177:243-50. doi:10.1016/0022-1759(94)90162-7

100. Wilkinson KA, Vordermeier MH, Kajtar J, Jurcevic S, Wilkinson R, Ivanyi J, et al. Modulation of peptide specific $\mathrm{T}$ cell responses by non-native flanking regions. Mol Immunol (1997) 34:1237-46. doi:10.1016/S0161-5890(98)00009-1
101. Wilkinson KA, Hudecz F, Vordermeier HM, Ivanyi J, Wilkinson RJ. Enhancement of the $\mathrm{T}$ cell response to a mycobacterial peptide by conjugation to synthetic branched polypeptide. Eur J Immunol (1999) 29:2788-96. doi:10.1002/ (SICI) 1521-4141(199909)29:09<2788::AID-IMMU2788>3.0.CO;2-4

102. Gowthaman U, Singh V, Zeng W, Jain S, Siddiqui KF, Chodisetti SB, et al. Promiscuous peptide of $16 \mathrm{kDa}$ antigen linked to Pam2Cys protects against Mycobacterium tuberculosis by evoking enduring memory T-cell response. J Infect Dis (2011) 204:1328-38. doi:10.1093/infdis/jir548

103. Hewitt J, Coates AR, Mitchison DA, Ivanyi J. The use of murine monoclonal antibodies without purification of antigen in the serodiagnosis of tuberculosis. J Immunol Methods (1982) 55:205-11. doi:10.1016/0022-1759(82)90032-1

104. Sinha S, Sengupta U, Ramu G, Ivanyi J. Serological survey of leprosy and control subjects by a monoclonal antibody-based immunoassay. Int J Lepr Other Mycobact Dis (1985) 53:33-8.

105. Bothamley GH, Rudd R, Festenstein F, Ivanyi J. Clinical value of the measurement of Mycobacterium tuberculosis specific antibody in pulmonary tuberculosis. Thorax (1992) 47:270-5. doi:10.1136/thx.47.4.270

106. Wilkins EG, Ivanyi J. Potential value of serology for diagnosis of extrapulmonary tuberculosis. Lancet (1990) 336:641-4. doi:10.1016/0140-6736(90) 92144-7

107. Bothamley G, Batra H, Ramesh V, Chandramui A, Ivanyi J. Serodiagnostic value of the 19 kilodalton antigen of Mycobacterium tuberculosis in Indian patients. Eur J Clin Microbiol Infect Dis (1992) 11:912-5. doi:10.1007/BF01962372

108. Ivanyi J. Serodiagnosis of tuberculosis: due to shift track. Tuberculosis (Edinb) (1989) 92:31-7. doi:10.1016/j.tube.2011.09.001

109. Chandramuki A, Bothamley GH, Brennan PJ, Ivanyi J. Levels of antibody to defined antigens of Mycobacterium tuberculosis in tuberculous meningitis. J Clin Microbiol (1989) 27:821-5.

110. Ivanyi J. Could active case finding reduce the transmission of tuberculosis? The Lancet (2014) 383:1035-6. doi:10.1016/S0140-6736(14)60510-9

111. Gaseitsiwe S, Valentini D, Mahdavifar S, Magalhaes I, Hoft DF, Zerweck J, et al. Pattern recognition in pulmonary tuberculosis defined by high content peptide microarray chip analysis representing 61 proteins from M. tuberculosis. PLoS One (2008) 3:e3840. doi:10.1371/journal.pone.0003840

112. Balu S, Reljic R, Lewis MJ, Pleass RJ, McIntosh R, van Kooten C, et al. A novel human IgA monoclonal antibody protects against tuberculosis. J Immunol (2011) 186:3113-9. doi:10.4049/jimmunol.1003189

113. Buccheri S, Reljic R, Caccamo N, Meraviglia S, Ivanyi J, Salerno A, et al. Prevention of the post-chemotherapy relapse of tuberculous infection by combined immunotherapy. Tuberculosis (Edinb) (2009) 89:91-4. doi:10.1016/j.tube.2008. 09.001

114. Harris DP, Vordermeier HM, Arya A, Bogdan K, Moreno C, Ivanyi J. Immunogenicity of peptides for B cells is not impaired by overlapping T-cell epitope topology. Immunology (1996) 88:348-54. doi:10.1046/j.1365-2567.1996.d01673.x

115. Engberg J, Krogsgaard M, Fugger L. Recombinant antibodies with the antigenspecific, MHC restricted specificity of $\mathrm{T}$ cells: novel reagents for basic and clinical investigations and immunotherapy. Immunotechnology (1999) 4:273-8.

116. Engberg J, Yenidunya AF, Clausen R, Jensen LB, Sorensen P, Kops P, et al. Human recombinant Fab antibodies with T-cell receptor-like specificities generated from phage display libraries. Methods Mol Biol (2003) 207:161-77.

117. Cohen CJ, Denkberg G, Lev A, Epel M, Reiter Y. Recombinant antibodies with MHC-restricted, peptide-specific, T-cell receptor-like specificity: new tools to study antigen presentation and TCR-peptide-MHC interactions. J Mol Recognit (2003) 16:324-32. doi:10.1002/jmr.640

118. Denkberg G, Reiter Y. Recombinant antibodies with T-cell receptor-like specificity: novel tools to study MHC class I presentation. Autoimmun Rev (2006) 5:252-7. doi:10.1016/j.autrev.2005.07.004

119. Liddy N, Molloy PE, Bennett AD, Boulter JM, Jakobsen BK, Li Y. Production of a soluble disulfide bond-linked TCR in the cytoplasm of Escherichia coli trxB gor mutants. Mol Biotechnol (2010) 45:140-9. doi:10.1007/s12033-010-9250-0

120. Michaeli Y, Denkberg G, Sinik K, Lantzy L, Chih-Sheng C, Beauverd C, et al. Expression hierarchy of $\mathrm{T}$ cell epitopes from melanoma differentiation antigens: unexpected high level presentation of tyrosinase-HLA-A2 Complexes revealed by peptide-specific, MHC-restricted, TCR-like antibodies. J Immunol (2009) 182:6328-41. doi:10.4049/jimmunol.0801898

121. Epel M, Carmi I, Soueid-Baumgarten S, Oh SK, Bera T, Pastan I, et al. Targeting TARP, a novel breast and prostate tumor-associated antigen, with 
T cell receptor-like human recombinant antibodies. Eur J Immunol (2008) 38:1706-20. doi:10.1002/eji.200737524

122. Klechevsky E, Gallegos M, Denkberg G, Palucka K, Banchereau J, Cohen C, et al. Antitumor activity of immunotoxins with T-cell receptor-like specificity against human melanoma xenografts. Cancer Res (2008) 68:6360-7. doi:10.1158/0008-5472.CAN-08-0928

123. Caccamo N, Milano S, Di Sano C, Cigna D, Ivanyi J, Krensky AM, et al. Identification of epitopes of Mycobacterium tuberculosis 16- $\mathrm{kDa}$ protein recognized by human leukocyte antigen-A*0201 CD8(+) T lymphocytes. J Infect Dis (2002) 186:991-8. doi:10.1086/344174

124. Geluk A, van Meijgaarden KE, Franken KL, Drijfhout JW, D’Souza S, Necker A, et al. Identification of major epitopes of Mycobacterium tuberculosis AG85B that are recognized by HLA- $A^{\star} 0201$-restricted CD8+ T cells in HLA-transgenic mice and humans. J Immunol (2000) 165:6463-71.

125. Chang ST, Linderman JJ, Kirschner DE. Multiple mechanisms allow Mycobacterium tuberculosis to continuously inhibit MHC class II-mediated antigen presentation by macrophages. Proc Natl Acad Sci U S A (2005) 102:4530-5. doi:10.1073/pnas.0500362102

126. Dadaglio G, Nelson CA, Deck MB, Petzold SJ, Unanue ER. Characterization and quantitation of peptide-MHC complexes produced from hen egg lysozyme using a monoclonal antibody. Immunity (1997) 6:727-38. doi:10.1016/S10747613(00)80448-3

127. Croft NP, Smith SA, Wong YC, Tan CT, Dudek NL I, Flesch E, et al. Kinetics of antigen expression and epitope presentation during virus infection. PLoS Pathog (2013) 9:e1003129. doi:10.1371/journal.ppat.1003129

128. Molloy A, Laochumroonvorapong P, Kaplan G. Apoptosis, but not necrosis, of infected monocytes is coupled with killing of intracellular bacillus CalmetteGuerin. J Exp Med (1994) 180:1499-509. doi:10.1084/jem.180.4.1499

129. Fratazzi C, Arbeit RD, Carini C, Balcewicz-Sablinska MK, Keane J, Kornfeld H, et al. Macrophage apoptosis in mycobacterial infections. J Leukoc Biol (1999) 66:763-4.

130. Matthey B, Engert A, Klimka A, Diehl V, Barth S. A new series of pET-derived vectors for high efficiency expression of Pseudomonas exotoxin-based fusion proteins. Gene (1999) 229:145-53. doi:10.1016/S0378-1119(99)00038-4

131. Dalken B, Giesubel U, Knauer SK, Wels WS. Targeted induction of apoptosis by chimeric granzyme B fusion proteins carrying antibody and growth factor domains for cell recognition. Cell Death Differ (2006) 13:576-85. doi:10.1038/sj.cdd. 4401773

132. Kurschus FC, Kleinschmidt M, Fellows E, Dornmair K, Rudolph R, Lilie H, et al. Killing of target cells by redirected granzyme $\mathrm{B}$ in the absence of perforin. FEBS Lett (2004) 562:87-92. doi:10.1016/S0014-5793(04)00187-5

133. Dharap SS, Qiu B, Williams GC, Sinko P, Stein S, Minko T. Molecular targeting of drug delivery systems to ovarian cancer by $\mathrm{BH} 3$ and $\mathrm{LHRH}$ peptides. J Control Release (2003) 91:61-73. doi:10.1016/S0168-3659(03)00209-8

134. Moreau C, Cartron PF, Hunt A, Meflah K, Green DR, Evan G, et al. Minimal $\mathrm{BH} 3$ peptides promote cell death by antagonizing anti-apoptotic proteins. J Biol Chem (2003) 278:19426-35. doi:10.1074/jbc.M209472200

135. Condos R, Raju B, Canova A, Zhao BY, Weiden M, Rom WN, et al. Recombinant gamma interferon stimulates signal transduction and gene expression in alveolar macrophages in vitro and in tuberculosis patients. Infect Immun (2003) 71:2058-64. doi:10.1128/IAI.71.4.2058-2064.2003

136. Cousens LP, Najafian N, Mingozzi F, Elyaman W, Mazer B, Moise L, et al. In vitro and in vivo studies of IgG-derived Treg epitopes (Tregitopes): a promising new tool for tolerance induction and treatment of autoimmunity. J Clin Immunol (2013) 33(Suppl 1):S43-9. doi:10.1007/s10875-012-9762-4

137. Cousens LP, Su Y, McClaine E, Li X, Terry F, Smith R, et al. Application of IgG-derived natural Treg epitopes (IgG Tregitopes) to antigen-specific tolerance induction in a murine model of type 1 diabetes. J Diabetes Res (2013) 2013:621693. doi:10.1155/2013/621693

138. Cousens LP, Tassone R, Mazer BD, Ramachandiran V, Scott DW, De Groot AS. Tregitope update: mechanism of action parallels IVIg. Autoimmun Rev (2013) 12:436-43. doi:10.1016/j.autrev.2012.08.017

139. Olivares N, Leon A, Lopez Y, Puig A, Cadiz A, Falero G, et al. The effect of the administration of human gamma globulins in a model of BCG infection in mice. Tuberculosis (Edinb) (2006) 86:268-72. doi:10.1016/j.tube.2006.01.006

140. Olivares N, Puig A, Aguilar D, Moya A, Cadiz A, Otero O, et al. Prophylactic effect of administration of human gamma globulins in a mouse model of tuberculosis. Tuberculosis (Edinb) (2009) 89:218-20. doi:10.1016/j.tube.2009.02.003

141. Hougardy JM, Place S, Hildebrand M, Drowart A, Debrie AS, Locht C, et al. Regulatory $\mathrm{T}$ cells depress immune responses to protective antigens in active tuberculosis. Am J Respir Crit Care Med (2007) 176:409-16. doi:10.1164/rccm. 200701-084OC

142. Boer MC, van Meijgaarden KE, Bastid J, Ottenhoff TH, Joosten SA. CD39 is involved in mediating suppression by Mycobacterium bovis BCG-activated human CD8(+) CD39(+) regulatory T cells. Eur J Immunol (2013) 43:1925-32. doi:10.1002/eji.201243286

143. Li L, Lao SH, Wu CY. Increased frequency of CD4(+)CD25(high) Treg cells inhibit BCG-specific induction of IFN-gamma by CD4(+) T cells from TB patients. Tuberculosis (Edinb) (2007) 87:526-34. doi:10.1016/j.tube.2007. 07.004

144. Quinn KM, McHugh RS, Rich FJ, Goldsack LM, de Lisle GW, Buddle BM, et al. Inactivation of CD4+ CD25+ regulatory T cells during early mycobacterial infection increases cytokine production but does not affect pathogen load. Immunol Cell Biol (2006) 84:467-74. doi:10.1111/j.1440-1711.2006. 01460.x

145. Quinn KM, Rich FJ, Goldsack LM, de Lisle GW, Buddle BM, Delahunt B, et al. Accelerating the secondary immune response by inactivating CD4(+)CD25(+) T regulatory cells prior to BCG vaccination does not enhance protection against tuberculosis. Eur J Immunol (2008) 38:695-705. doi:10.1002/eji.200737888

Conflict of Interest Statement: The author declares that the research was conducted in the absence of any commercial or financial relationships that could be construed as a potential conflict of interest.

Received: 04 February 2014; paper pending published: 23 February 2014; accepted: 03 March 2014; published online: 24 March 2014.

Citation: Ivanyi J (2014) Function and potentials of M. tuberculosis epitopes. Front. Immunol. 5:107. doi: 10.3389/fimmu.2014.00107

This article was submitted to Microbial Immunology, a section of the journal Frontiers in Immunology.

Copyright (c) 2014 Ivanyi. This is an open-access article distributed under the terms of the Creative Commons Attribution License (CC BY). The use, distribution or reproduction in other forums is permitted, provided the original author(s) or licensor are credited and that the original publication in this journal is cited, in accordance with accepted academic practice. No use, distribution or reproduction is permitted which does not comply with these terms. 